\title{
DRUG-INDUCED ORAL ULCERATIONS: CASE REPORT
}

\author{
Vanja Vučičević Boras ${ }^{1}$, Snježana Židovec-Lepej ${ }^{2}$, Branka Marinovićs ${ }^{3}$, Sven Seiwerth ${ }^{4}$, \\ Ivana Škrinjar ${ }^{1}$, Dražen Pulanićc ${ }^{5,6}$ and Danica Vidović Juras ${ }^{1}$
}

${ }^{1}$ Department of Oral Medicine, School of Dentistry, University of Zagreb and Zagreb University Hospital Center;

${ }^{2}$ Department of Virology, Dr Fran Mihaljević Clinical Hospital for Infectious Diseases;

${ }^{3}$ Clinical Department of Dermatology and Venereology, ${ }^{4}$ Department of Pathology, ${ }^{5}$ Division of Hematology,

Department of Internal Medicine, Zagreb University Hospital Center and School of Medicine, University of Zagreb, Zagreb; ${ }^{6}$ Osijek School of Medicine, Josip Juraj Strossmayer

University of Osijek, Osijek, Croatia

\begin{abstract}
SUMMARY - A 70-year-old patient was admitted to the Department of Oral Medicine for multiple oral ulcerations on the left buccal mucosa, around $0.5 \mathrm{~cm}$ in diameter, as well as on the gingiva. Otherwise, the patient suffered from chronic lymphocytic leukemia, hypogammaglobulinemia, chronic renal insufficiency, with complete afunction of the right kidney, asthma, hypertension, gastritis and prostate hyperplasia. Differential diagnosis of oral ulcerations included drug induced oral ulcerations, paraneoplastic pemphigus, viral ulcerations (cytomegalovirus, herpes simplex viruses), fungal ulcerations (candidiasis, aspergillosis, histoplasmosis, cryptococcosis) and bacterial ulcerations, as well as neutropenic ulcers. One of the possible explanations was that the lesions were due to the use of drugs, the more so as oral lesions evolved when the doses of allopurinol and chlorambucil were increased, and subsided when the doses of both drugs were decreased. However, we could not establish for sure whether the lesions were due to allopurinol or chlorambucil. According to literature data, allopurinol is one of the most frequent drugs known to induce skin adverse reactions, therefore we assumed that it was the culprit drug. Unfortunately, several weeks later the patient died from sepsis, pneumonia with respiratory insufficiency and multiorgan failure.
\end{abstract}

Key words: Oral ulcer; Drug-related side effects and adverse reactions; Case reports

\section{Introduction}

Sometimes it is very difficult to find out what is the exact cause of oral ulcers, especially in patients that are immunosuppressed and take many drugs. Oral ulcers can be induced by the following causes: 1) traumatic; 2) microbial (viral, bacterial and fungal); 3) autoimmune mediated such as recurrent aphthous ulcers; 4) related to systemic diseases such as gastrointestinal (gluten enteropathy and Crohn's disease) and hematopoietic ones such as iron deficiency and neutropenia;

Correspondence to: Vanja Vučičević Boras, DDM, School of Dental Medicine, University of Zagreb, Gundulićeva 5, HR-10000 Zagreb, Croatia

E-mail: boras@sfzg.hr

Received July 8, 2014, accepted January 19, 2015
5) vesiculobullous diseases such as pemphigus, pemphigoid; 6) malignant oral diseases such as oral squamous cell carcinoma, diffuse large B cell lymphoma and metastases; 7) self-inflicted lesions in psychiatric patients such as bulimia; 8) adverse drug reactions; and 9) neutropenic ulcerations ${ }^{1}$.

Oral ulcers are well known side effects of drug therapy; however, their exact etiopathogenesis is poorly understood. It is important to define when the ulcerations began, or if they worsened de novo upon increased drug dosage ${ }^{2}$, as in our case.

It is well known that nonsteroidal anti-inflammatory drugs (NSAIDs) and beta blockers (labetalol, captopril, nicorandil) may lead to the development of oral ulceration. Nicorandil induced oral ulcerations are probably caused by its metabolites. It is known that 
there are large individual variations in the activity of enzyme nicotinamide $\mathrm{N}$-methyltranferase that catalyzes methyl conjugation of nicotinamide, an intermediate formed by denitration of nicorandil. NSAIDs may cause mucosal ulceration due to local vasoconstriction. Mouth ulcers can occur as side effects of immunosuppressive therapy which may lead to activation of herpes virus or other viruses such as cytomegalovirus (CMV). Phenylbutazone can cause agranulocytosis which may manifest with oral ulcerations. The only proper diagnosis of the drug-induced oral ulceration is re-challenge, which is unethical unless the drug is unreplaceable. Re-challenge poses the risk of anaphylactic reaction ${ }^{3}$.

Oral adverse reactions to drugs depend on the dose and type of medication, as well as on individual differences related to the patient. Oral adverse reactions to drugs may be rapid but can also develop a few years after the drug has been initiated. In most drug-induced oral reactions, improvement of clinical symptoms occurs after dose reduction or upon discontinuation of the offending drug ${ }^{4,5}$. Hernandez et al. ${ }^{6}$ have described a case of a patient in whom resolution of oral ulceration occurred after decreasing the dosage of tacrolimus. It seems that this phenomenon may be related to the drug half-life. Of course, severe reactions require rapid withdrawal of the offending drug.

So far, some drugs have been implicated in the etiology of oral ulcers such as sodium lauryl sulfate, sertraline hydrochloride, NSAIDs, ferrous sulfate, lamotrigine, tacrolimus, mycophenolate mofetil, sirolimus, nicorandil, captopril, labetalol, calcium channel blockers, foscarnet, alendronate, protease inhibitors, interferon and 2'3'-dideoxycytidine, aspirin, pancreatic supplements, metamizole, tiotropium bromide and sulfonamides ${ }^{7}$.

\section{Case Report}

A 70-year-old male patient was referred to our Department. Clinically, the lesions appeared as three oral ulcerations on his left buccal mucosa approximately $0.5 \mathrm{~cm}$ in diameter and the same type of lesions could be seen on the upper and lower gingiva (Figs. 1 and 2). The whole oral mucosa was thinned and pale.

Detailed medical history revealed that he suffered from chronic lymphocytic leukemia, hypogammaglobulinemia, chronic renal insufficiency, with complete

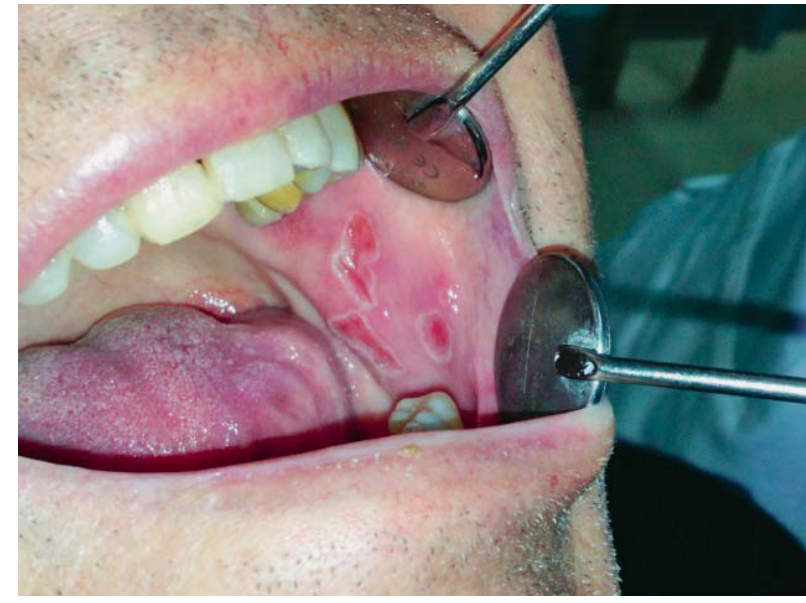

Fig. 1. Lesions on the left buccal mucosa on admission.

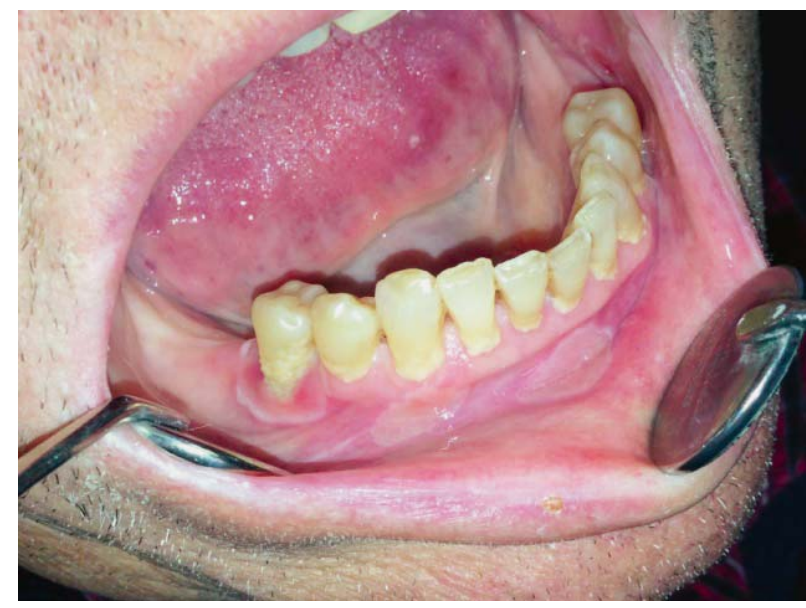

Fig. 2. Lesions on the mandibular labial and gingival mucosa.

afunction of the right kidney, asthma, degenerative laryngopathy, hypertension, gastritis and prostate hyperplasia.

Upon admission to our Department, he was taking methylprednisolone (Medrol), aciclovir (Herplex), pantoprazole (Controloc), allopurinol (Alopurinol), lercanidipine (Lercanil), losartan (Losartic), ciclesonide (Alvesco), albuterol sulfate (Ventolin), loratadine (Rinolan), tamsulosine (Omnic), diazepam (Normabel), budesonidum (Tafen) and montelukast (Melarth).

Complete blood count revealed the following findings: L $4.0\left(x 10^{9}\right)$ (normal range 3.4-9.7); erythrocytes $3.71\left(\mathrm{x} 10^{12}\right)$ (4.34-5.72); hemoglobin $108 \mathrm{~g} / \mathrm{L}(138-$ 175); hematocrit 0.33 (L/L) (0.415-0.530); $\mathrm{MCV}$ 


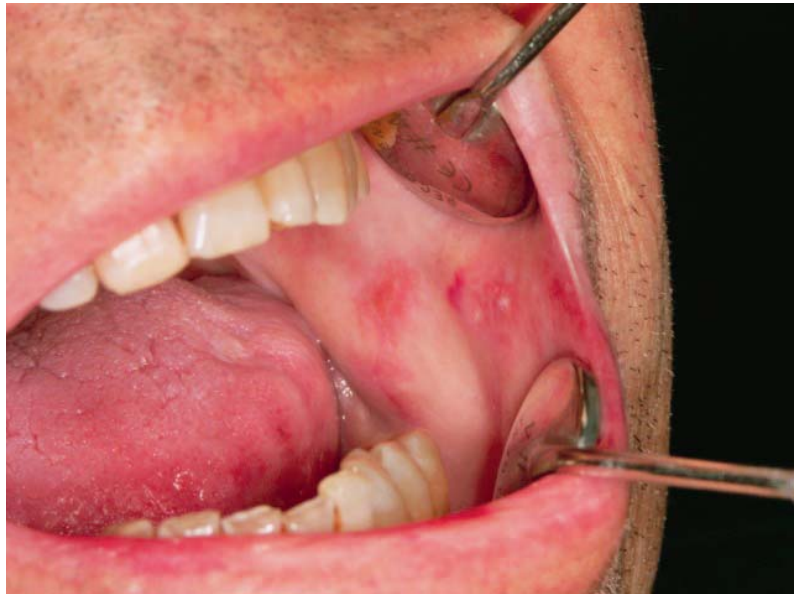

Fig. 3. Healed lesions on buccal mucosa.

88.9 (fL) (83-97.2); platelets 87 (x109/L) (158-424); C-reactive protein $43.7(<5)$; neutrophil range $66 \%$.

Histopathologic finding showed granulation tissue with rare to medium abundant mononuclear inflammatory infiltration; however, no macrophages with inclusions were seen. Direct and indirect immunofluorescence (DIF and IIF) finding showed no immunoglobulin and complement deposits.

At presentation, we thought the patient had CMV induced oral lesions and he was referred for viral blood tests (real time PCR, Qiagen CMV LC PCR Kit), which revealed CMV viremia. He was immediately administered valaganciclovir therapy together with acyclovir, fluconazole and azithromycin, with local improvement. Our working diagnosis was drug (allopurinol or chlorambucil) induced oral ulceration, as the lesions started when allopurinol dose was increased from $100 \mathrm{mg}$ to $300 \mathrm{mg}$ and subsided when allopurinol dose was $200 \mathrm{mg}$. At the same time, chlorambucil was reduced from the dose of $16 \mathrm{mg}$ to $2 \mathrm{mg}$ because leukocyte number was normalized. The lesions began to heal (Fig. 3). Unfortunately, several weeks later, the patient died from sepsis, pneumonia with respiratory insufficiency and multiorgan failure.

\section{Discussion}

Notwithstanding the clinical importance of treatment-related toxicities, dermatologic and mucosal disturbances may also precede, coincide or follow the diagnosis of cancer. This case was quite peculiar due to the simultaneous occurrence of oral ulceration and certain systemic conditions which may have led to the development of oral ulceration in this patient. The histopathologic finding was not suggestive of viral infection (neither herpes nor CMV) or fungal infection. Moreover, immunohistochemistry of oral lesions did not reveal the presence of either CMV or herpes simplex virus (HSV). DIF and IIF were also negative, therefore the diagnosis of pemphigus, paraneoplastic pemphigus and pemphigoid was discarded. We thought that maybe this was fungal infection (candidal or cryptococcal), as the lesions cleared when fluconazole was introduced, however, no fungi were found in the histopathology specimen.

At the end, our working diagnosis was drug (allopurinol or chlorambucil) induced oral ulceration, as the lesions started when allopurinol dose was increased from $100 \mathrm{mg}$ to $300 \mathrm{mg}$ and the lesions subsided when allopurinol dose was reduced to $200 \mathrm{mg}$ as kidney function improved. At the same time, chlorambucil was reduced from the dose of $16 \mathrm{mg}$ to $2 \mathrm{mg}$ because leukocyte count was normalized. It is well known that allopurinol dose increase leads to the more frequent occurrence of Stevens-Johnson syndrome (SJS) and toxic epidermal necrolysis (TEN). Furthermore, the use of $200 \mathrm{mg}$ or more of allopurinol daily was associated with a higher risk of SJS or TEN compared with lower daily doses, as reported by Halevy et al. ${ }^{8}$.

There have been few case reports on skin granuloma annulare in patients as a side effect of allopurinol; however, to our knowledge, there are not many case reports on Pubmed on oral manifestations of allopurinol therapy. Abdollahi and Radfar ${ }^{9}$ have reported that allopurinol might induce erythema multiforme, oral ulceration and oral lichenoid changes. Marra and Wunderle ${ }^{10}$ report the first case of toxic epidermal necrolysis associated with allopurinol therapy, which initially presented with oral ulceration. Chau et al. ${ }^{11}$ describe oral lichenoid reactions due to allopurinol therapy in four patients.

We cannot describe the underlying mechanism by which allopurinol might lead to development of oral ulcers. It is possible that the mechanisms include immune complex deposition, an immune response directed against the metabolites of allopurinol or allopurinol hypersensitivity exclusively localized to oral $\mathrm{mu}-$ cosa, as it has been described for allopurinol induced skin lesions such as granulomatous dermatitis ${ }^{12,13}$. 
Regarding chlorambucil, there have also been few case reports on oral and skin induced lesions. Pietrantonio et al. ${ }^{14}$ have reported a case of a patient who developed confluent maculopapular erythema and large flaccid bullae on the trunk, legs and mucous membranes, with fever up to $38^{\circ} \mathrm{C}$. TEN was confirmed by skin patch test followed by skin biopsy.

Levin and Libster have reported two cases of high fever and progressive lymphadenopathy in patients treated with chlorambucil. The authors conclude that allergic reactions to chlorambucil are rare, however, previously urticaria, angioedema, rashes, TEN, drug fever and one case of immune hemolytic anemia have been described ${ }^{15}$.

The case presented shows that oral finding looking like a CMV infection probably was a drug-induced oral lesion (due to either allopurinol or chlorambucil).

\section{References}

1. Porter SR, Leao JC. Oral ulcer and its relevance to systemic disorders. Aliment Pharmacol Ther. 2005;21:295-31.

2. Naranjo J, Poniachik J, Cisco D, Contreras J, Oksenberg D, Valera JM, et al. Oral ulcers produced by mycophenolate mofetil in two liver transplant patients. Transplantat Proc. 2007;39:612-4.

3. Vučičević Boras V, Andabak-Rogulj A, Brailo V, Vidović Juras D, Gabrić D, Kraljević-Šimunković S, Vrdoljak DV. Adverse drug reactions in the oral cavity. Acta Clin Croat. 2015 Jun;54(2):208-15.

4. Healy CM, Smyth Y, Flint SR. Persistent nicorandil induced oral ulceration. Heart. 2004;90:37-8.
5. Bertini F, Sena Costa NC, Haberbeck Brandao AA, Rodrigues Cavalcante AS, Dias Almeida J. Ulceration of the oral mucosa induced by antidepressant medication. J Med Case Rep. 2009; 3:98. doi: 10.1186/1752-1947-3-98

6. Hernandez G, Jimenez C, Arriba L, Moreno E, Lucas M. Resolution of oral ulcerations after decreasing the dosage of tacrolimus in a liver transplantation recipient. Oral Surg Oral Med Oral Pathol Oral Radiol Endod. 2001;92(5):526-31.

7. Scully C, Bagan JV. Adverse drug reactions in the orofacial region. Crit Rev Oral Biol Med. 2004;15:221-39.

8. Halevy S, Ghislain PD, Mockenhaupt M, et al. Allopurinol is the most common cause of Stevens-Johnson syndrome and toxic epidermal necrolysis in Europe and Israel. J Am Acad Dermatol. 2008;58:25-32.

9. Abdollahi M, Radfar M. A review of drug-induced oral reactions. J Contemp Dent Pract. 2003;4(1):10-31.

10. Marra LM, Wunderle RC. Oral presentation of toxic epidermal necrolysis. J Oral Maxillofac Surg. 1982;40:59-61.

11. Chau NY, Reade PC, Rich AM, Hay KD. Allopurinol-amplified lichenoid reactions of the oral mucosa. Oral Surg. 1984;58:39-40.

12. Gordon K, Miteva M, Torchia D, Romanelli P. Allopurinolinduced palisaded neutrophilic and granulomatous dermatitis. Cutan Ocul Toxicol. 2012;31:338-40. doi: 10.3109/15569527. 2011.647180

13. Elasy T, Kaminsky D, Tracy M, Mehler PS. Allopurinol hypersensitivity syndrome revisited. West J Med. 1995;162:360-1.

14. Pietrantonio F, Moriconi L, Torino F, Romano A, Gargovich A. Unusual reaction to chlorambucil: a case report. Cancer Lett. 1990;54:109-11.

15. Levin M, Libster D. Allergic reaction to chlorambucil in chronic lymphocytic leukemia presenting with fever and lymphadenopathy. Leuk Lymphoma. 2005;46:1195-7.

Sažetak

\section{LIJEKOVIMA IZAZVANE ORALNE ULCERACIJE: PRIKAZ SLUČAJA}

\section{Vučičević Boras, S. Židovec-Lepej, B. Marinović, S. Seiwerth, I. Škrinjar, D. Pulanić i D. Vidović Juras}

Bolesnik u dobi od 70 godina upućen je na Zavod za oralnu medicinu zbog nekoliko oralnih ulceracija na lijevoj obraznoj sluznici veličine oko pola centimetra u promjeru te na gingivi. Inače je bolovao od kronične limfocitne leukemije, hipogamaglobulinemije, kronične bubrežne insuficijencije s potpunom afunkcijom desnog bubrega, astme, hipertenzije, gastritisa i hiperplazije prostate. Diferencijalna dijagnoza oralnih ulceracija uključivala je oralne ulceracije uslijed uzimanja lijekova, paraneoplastični pemfigus, virusne ulceracije (citomegalovirus, herpes simpleks viruse), gljivične ulceracije (kandidijaza, aspergiloza, histoplazmoza, kriptokokoza), bakterijske ulceracije te neutropenične ulceracije. Jedno od mogućih objašnjenja je bilo da su lezije vjerojatno nastale uslijed uzimanja lijekova, jer su se pojavile kada se doza alopurinola i klorambucila povećala, a počele su nestajati kada se doza tih lijekova smanjila. Ipak, nismo sigurni koji je od ova dva lijeka doveo do nastanka lezija, jer je nažalost nekoliko tjedana poslije bolesnik izdahnuo uslijed sepse, pneumonije i respiracijske insuficijencije te višeorganskog zatajenja.

Ključne riječi: Oralni ulkus; Uzimanje lijekova, popratni učinci i štetna djelovanja; Prikazi slučaja 